\title{
Long Non-Coding RNAs in Obesity-Induced Cancer
}

\author{
Mabel Yin-Chun Yau ${ }^{1}$, Lu Xu ${ }^{2}$, Chien-Ling Huang ${ }^{3}$ (1) and Chi-Ming Wong ${ }^{3, *}$ \\ 1 School of Medical and Health Sciences, Tung Wah College, Hong Kong, China; mabelyau@twc.edu.hk \\ Department of Medicine, The University of Hong Kong, Hong Kong, China; irisxu@hku.hk \\ 3 Department of Health Technology and Informatics, The Hong Kong Polytechnic University, \\ Hong Kong, China; cl.huang@polyu.edu.hk \\ * Correspondence: chi-ming.cm.wong@polyu.edu.hk; Tel.: +86-852-3400-8564
}

Received: 24 June 2018; Accepted: 27 August 2018; Published: 28 August 2018

\begin{abstract}
Many mechanisms of obesity-induced cancers have been proposed. However, it remains unclear whether or not long non-coding RNAs (lncRNAs) play any role in obesity-induced cancers. In this article, we briefly discuss the generally accepted hypotheses explaining the mechanisms of obesity-induced cancers, summarize the latest evidence for the expression of a number of well-known cancer-associated lncRNAs in obese subjects, and propose the potential contribution of lncRNAs to obesity-induced cancers. We hope this review can serve as an inspiration to scientists to further explore the regulatory roles of lncRNAs in the development of obesity-induced cancers. Those findings will be fundamental in the development of effective therapeutics or interventions to combat this life-threatening adverse effect of obesity.
\end{abstract}

Keywords: obesity; cancer; lncRNA; ANRIL; H19; HOTAIR

\section{Introduction}

Body weight increases when long-term energy intake exceeds energy expenditure, which triggers the increase of energy storage as fat in our body. Increase in body weight does not only enhance the risk of diabetes and cardiovascular diseases, but also contributes to several types of cancers $[1,2]$ and diminishes survival of cancer patients [3]. It was estimated that about $20 \%$ of cancer cases are caused by obesity [4]. Our understanding of the interrelationships between obesity and cancer risk have significantly improved in the last century [5]. Several hypotheses were proposed to explain why obesity may foster or promote cancers [6-8]. The generally accepted hypotheses are included below.

\subsection{Hyperinsulinemia}

Insulin resistance is a common characteristic of obese people [9]. Insulin resistance stimulates the pancreas to produce more insulin leading to hyperinsulinemia. A chronic high level of insulin can be harmful to our body because of its mitogenic and anti-apoptotic effects [10]. Elevated circulating insulin level potentially favors the growth and aggressiveness of cancers. In addition, hyperinsulinemia upregulates the expression and activity of insulin-like growth factor-1 (IGF-1) [11]. Insulin shares significantly high homology with IGF-1 and can interact with IGF-1 receptor (IGF-1R) [4]. As a high level of IGF-1 and dysregulation of IGF-1R signaling are also associated with tumor development [12], it is necessary to evaluate the administration level of native insulin or insulin analogue in terms of reducing cancer risk $[7,13]$.

\subsection{Dysregulation of the Adipokine Expression}

The main role of adipose tissue is not only energy storage [14]. Adipose tissue is also an important endocrine organ [15] producing hundreds of cytokines, the adipokines. Secretion profiles 
of adipokines are affected by the size, metabolic compositions of adipocytes [16], and their cellular populations [17]. For example, leptin is an adipokine predominantly produced by adipocytes that inhibits appetite [18]. Similar to the situation of insulin resistance, leptin resistance is also commonly found among overweight people. Moreover, leptin resistance is believed to be one of the leading drivers of weight gain [18]. Anti-apoptotic and mitogenic effects of leptin have been demonstrated on different cancer cell lines [19]. From reports, the significantly high circulating level of leptin is associated with enhanced cell proliferation and increased risks of cancers in the leptin resistance in obese subjects [20-22].

\subsection{Hypoxia}

Cells adjacent to the blood vessels are exposed to relatively higher $\mathrm{O}_{2}$ level than the cells away from the blood vessels. As fat accumulates in the adipose tissues during the development of obesity, the "well" vascularized adipocytes may become "poorly" vascularized [23]. Low oxygen tension (hypoxia) in adipose tissues triggers necrotic cell death and inflammation [24]. Hypoxia stimulates a complex cell signaling network such as hypoxia-inducible factor 1 (HIF-1) [25]. HIF-1 is a heterodimeric transcription factor, composed of HIF- $1 \alpha$ (or its analogs HIF- $2 \alpha$ and HIF- $3 \alpha$ ) and HIF-1 $\beta$ [26]. HIF-1 is the key of oxygen sensing mechanism in mammalian cells and plays a crucial role in the adaptation to hypoxic stress of the cancer cells [27]. HIF-1 $\alpha$ is constitutively transcribed and synthesized independently from $\mathrm{O}_{2}$ concentration, but HIF- $1 \alpha$ will be degraded quickly under normoxic conditions [26]. In other words, the stability of HIF-1 $\alpha$ increases under hypoxic conditions. Recent studies demonstrated the correlation of high-level HIF-1 associated with tumor metastasis and poor prognosis in patients [28]. Increased adipose HIF- $1 \alpha$ protein was detected with obesity-associated factors [29], which enhanced cancer progression [30].

\subsection{Chronic Inflammation}

Inflammatory pathways is an approach of host defense, but chronic low-level inflammation is suggested to cause cancers [31]. It is estimated that about $20 \%$ of cancers in humans are contributed by chronic inflammation [32]. Under inflammatory conditions, free radicals are produced from inflammatory cells and cause DNA damage [33]. A number of mechanisms of obese-related chronic inflammation and cancer were proposed. For instance, various adipokines are proven to be involved in the inflammatory processes [34]. However, the upregulation of adipokines is not totally associated with the size and number of adipocytes. In contrast, the expression level of anti-inflammatory adipokine, adiponectin, is decreased in obese subjects [35]. This net change of expression between proinflammatory and anti-inflammatory adipokine contributes to local and systemic inflammation in those who are obese [36].

In addition to the contribution of adipokines in inflammation, emerging evidence demonstrated that changes in gut microbiota composition and increased intestinal permeability of obese subjects promote the uptake of endotoxin (lipopolysaccharides, LPS) produced from intestinal microorganisms [37]. The systemic elevations of gut-derived LPS activate the pattern recognition receptors and initiate inflammatory cascades [38]. This model is supported by the increase in circulating endotoxin among obese individuals, and the decrease of LPS in individuals following weight loss and/or gut modulation therapy [37]. Dysbiosis or imbalance in gut microbiota has been associated with the pathogenesis of obesity [39]. The precise mechanism of obesity-associated inflammation is still being explored [37].

Other than the hypotheses mentioned above, genetic and epigenetic factors also play an important role in obesity-related cancers $[40,41]$. Diets and environmental factors can cause significant epigenetic changes [42] and affect the expression of genes, including genes that contain the sequences of long non-coding RNAs (lncRNAs). Recent studies demonstrated that the expression profiles of lncRNAs were found to be significantly different in obese and non-obese human subjects [43,44]. Moreover, numerous functional lncRNAs are involved in lipid metabolism and adipogenesis [45,46]. In this 
mini review, we summarize the emerging evidence of a link between lncRNAs, obesity, and cancers. The emerging findings for three well-known oncogenic lncRNAs (namely, antisense non-coding RNA in the INK4 locus (ANRIL), H19, and HOX transcript antisense RNA (HOTAIR)) and their potential roles in obesity-induced cancers are discussed. Understanding the potential roles of IncRNAs will provide insights to further develop prevention and treatment strategies for obese-related cancers.

\section{IncRNAs in Cancer and Energy Metabolism}

Most long lncRNAs synthesized by RNA polymerase II (RNA Pol II) are 5' capped, spliced, and polyadenylated by a similar transcriptional machinery to messenger RNA (mRNA) [47]. By definition, lncRNAs are transcripts longer than 200 nucleotides (nt), most of which are not translated into protein [48]. Interestingly, it was recently reported that protein translation indeed exists in about $40 \%$ of lncRNAs [49]. With the advancement of sequencing technologies and computation methods for transcriptome assembly, a large number of lncRNAs have been identified. According to the Encyclopedia of DNA Elements (ENCODE) project, more than 28,000 lncRNAs are encoded from 16,000 genes in human [50]. IncRNAs are implicated in a variety of biological processes and diseases, most notably in cancers [47,50,51]. Early studies focus on the regulatory role of lncRNAs on gene expression at transcriptional or post-transcriptional levels under pathophysiological conditions $[47,52,53]$. As several lncRNAs have been found in exosomes and are thus protected from endogenous RNases, they can be detected in body fluids such as blood and urine. In this regard, secreted lncRNAs may become valuable biomarkers for many diseases including cancers [54].

Recent studies demonstrated that many lncRNAs regulate adipogenesis [55] and lipid homeostasis [56]. Systematic transcriptome analysis was performed to evaluate the significance of lncRNAs in metabolic homeostasis by comprehensively profiling lncRNAs in key metabolic organs under different metabolic conditions. The findings demonstrated that many lncRNAs are regulated by nutrient factors and metabolic hormones [57]. Differentially expressed circulating lncRNAs were also reported in obese patients using microarray analysis [43]. Given the role of lncRNAs in metabolic homeostasis, the design of IncRNA-based therapies could be considered. Screening strategy using pharmacological compounds for the treatment of obese-related diseases can be further utilized [44]. Interestingly, a number of cancer related lncRNAs are dysregulated/co-expressed in obesity, suggesting that obesity-associated lncRNAs may promote cancers. Here, we summarize the emerging findings for three well-known oncogenic lncRNAs (namely, ANRIL, H19, and HOTAIR) and discuss their potential roles in obesity-induced cancers (Table 1 ).

Table 1. Summary of the recent findings on antisense non-coding RNA in the INK4 locus (ANRIL), H19, and HOX transcript antisense RNA (HOTAIR) in various human obesity-induced cancers.

\begin{tabular}{cccc}
\hline Type of Cancer & ANRIL & H19 & HOTAIR \\
\hline Endometrial cancer & Upregulated [58] & Upregulated [59] & Upregulated [60,61] \\
Esophageal adenocarcinoma & Upregulated [62] & Upregulated [63,64] & Upregulated [65,66] \\
Liver cancer & Upregulated [67,68] & Upregulated [69], Downregulated [70] & Upregulated [71] \\
Pancreatic cancer & Upregulated [72,73] & Upregulated [74] & Upregulated [75,76] \\
Colorectal cancer & Upregulated [77,78] & Upregulated [64,79], Downregulated [80] & Upregulated [81,82] \\
Gallbladder cancer & Upregulated [83] & Upregulated [84,85] & Upregulated [86] \\
Breast cancer & Upregulated [87] & Upregulated [88] & Upregulated [89] \\
Ovarian cancer & Upregulated [90] & Upregulated [91] & Upregulated [92] \\
Thyroid cancer & Upregulated [93] & Downregulated [94] & Upregulated [95,96] \\
\hline
\end{tabular}

\subsection{Antisense Non-Coding RNA in the INK4 Locus}

ANRIL (antisense non-coding RNA in the INK4 locus; also known as CDKN2B-AS1) is transcribed as a $\sim 3.8 \mathrm{~kb}$ nucleotide-long lncRNA from the short arm of human chromosome 9 near INK4/ARF (INK4B-ARF-INK4A) locus [97]. INK4/ARF locus encompasses three important tumor suppressors, p14(ARF), p15(INK4b), and p16(INK4a) [98]. p15(INK4b) and p16(INK4a) are CD1/6 inhibitors that activate $\mathrm{pRb}$, whereas $\mathrm{p} 14(\mathrm{ARF})$ is an Mdm2 inhibitor that activates $\mathrm{p} 53$ [98]. The genes at this locus 
cause cell cycle arrest. Deletion, mutation, or transcriptional silence of the genes at this locus lead to $30-40 \%$ of human tumors [99].

The expression of ANRIL and the tumor suppressor genes at INK4/ARF locus is highly coordinated through a shared bidirectional promoter [100]. ANRIL is also one of the most up-regulated lncRNAs in cancers [101]. A recent study demonstrated that the expression of ANRIL is transcriptionally induced by DNA damage, especially at the late stage of the DNA damage response (DDR) [102]. DNA damage induces the expression of the genes ( $p 14, p 15$, and $p 16)$ at the INK4/ARF locus. ANRIL acts as homeostatic regulator to escape from the DDR activity by downregulating the expression of $p 14, p 15$, and $p 16$ in the INK4/ARF locus [102]. In precancerous lesions, the aberrant expression of ANRIL leads to genomic instability by blocking the control of the DDR mechanism. The mechanism is further supported by a recent study, demonstrating that the ATM-E2F1 signaling pathway induces ANRIL overexpression [72].

In addition, ANRIL can directly interact with and recruit polycomb repressive complex-2 (PRC2) complex to repress the expression of $p 15$ (INK4b) [99] and genes at the CDKN2A/B locus [97]. It is linked to poor prognosis of cancers by silencing this tumor suppressor locus. Insulator binding protein CTCF (also known as 11-zinc finger protein or CCCTC-binding factor) is one of the key transcription factors that regulates the expression of ANRIL and these three tumor suppressor genes at the INK4/ARF locus by modulating the chromatin architecture [103]. The recruitment of CTCF is dependent on the differential DNA methylation [104]. The CpG methylation of DNA disrupts the binding of CTCF to DNA [105], which contributes to gene silencing at the locus permanently [103].

Numerous polymorphisms located at the ANRIL locus have been highly associated with increased risk of diabetes and cardiovascular diseases (Table 2) [97,106,107]. Interestingly, the lower level of CPG methylation within the promoter of ANRIL at birth is associated with increased cardiovascular risk [108] and adiposity [109] at later childhood. This association derived from promoter methylation on ANRIL and adiposity was also determined in human tissues at various developmental stages [109]. As mentioned above, $\mathrm{CpG}$ methylation at the promoter of ANRIL also affects the expression of suppressor genes at the INK4/ARF locus. Further studies are required to reveal the important functions of ANRIL, in particular the incidence of cancers in obese children.

Table 2. Single-nucleotide polymorphisms (SNPs) in ANRIL locus associated with diabetes and cardiovascular diseases.

\begin{tabular}{cccc}
\hline SNP-ID & Related Diseases & Remarks & References \\
\hline rs10757278 & Myocardial infarction & G-allele was associated with & {$[110]$} \\
rs2891168 & Coronary artery disease & lower triglyceride level & {$[111,112]$} \\
rs10811661 & Type 2 diabetes & {$[113]$} \\
rs10965215 and rs10738605 & Myocardial infarction & {$[114]$} \\
rs10757274 and rs1333042 & Coronary artery disease & {$[115]$} \\
rs10757278 & $\begin{array}{c}\text { Major adverse cardio-vascular event (MACE) } \\
\text { in patients starting on hemodialysis }\end{array}$ & Reduced $\beta$-cell proliferation & {$[116]$} \\
rs564398 & Type 2 diabetes &
\end{tabular}

Furthermore, a recent study on genome-wide expression profiling demonstrated that downregulation of ANRIL transcripts containing exon 13 is correlated with the decrease in the expression of ADIPOR1, VAMP3, and C11ORF10 [117]. These observations are associated with various metabolic traits via glucose and fatty acid metabolism [117]. This indicated that ANRIL might have a potential function in regulating energy metabolism. In addition, further determining the differentially expressed combination of exons in different conditions is required for multi-exonic lncRNAs [118,119]. 


\section{2. $H 19$}

H19 is encoded from a 2.7 kilobases gene, which is maternally expressed and paternally imprinted, and is located closely to the telomeric region of chromosome 11 (Figure 1) [120]. H19 was first identified as one of the most abundant RNAs in the developing mouse embryo, and its expression is repressed in all murine tissues except skeletal muscle [121]. That is why H19 was first named ASM (adult skeletal muscle) [122]. The nucleotide sequence of rodent and human H19 is evolutionarily conserved [121]. During mammalian development, $H 19$ expression is predominantly regulated by DNA methylation at imprinting control regions on its promoter [123]. Aberrant relaxation of imprinted $H 19$ has been detected in a wide variety of cancers [124]. As H19 play a crucial role in embryogenesis and controls the expression of two major pluripotency factors-Oct4 and Sox2 [125], it promotes cancer stemness [126], which is associated with poor prognosis in cancer patients [127].

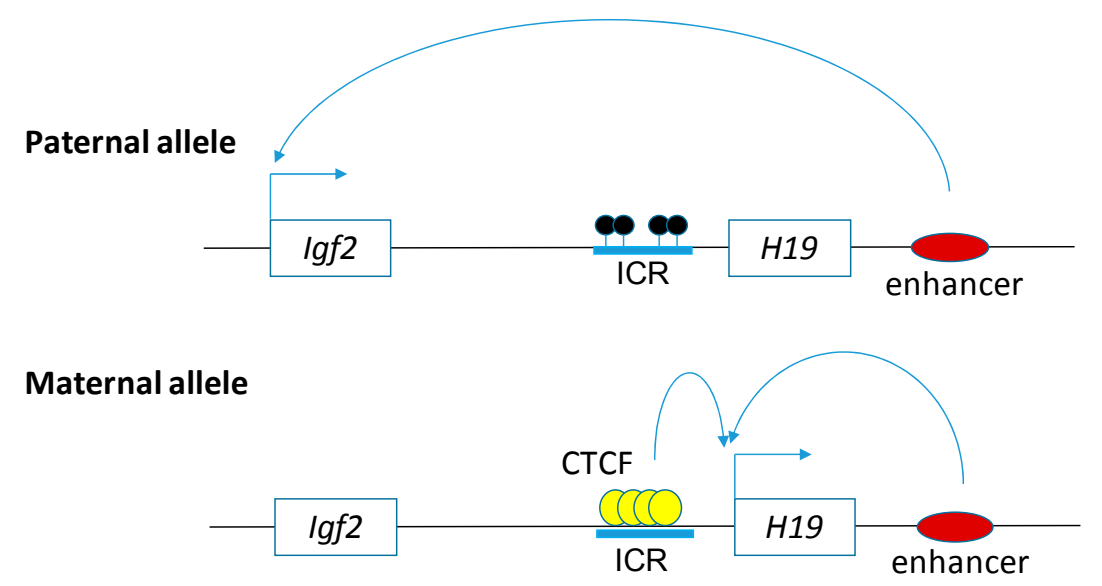

Figure 1. The epigenetic state of imprinting control region on the Igf2-H19 locus determines the expression pattern. Regulation of maternal and paternal expression in the Igf2-H19 imprinted domain is controlled by genomic DNA methylation. The open boxes represent the genes Igf 2 and H19, and the blue boxes represent the imprinting control region (ICR). The close lollipops represent methylated CpG islands. The yellow and red circles represent the CCCTC binding factor (CTCF) insulator protein and enhancer, respectively. The arrows from the boxes indicate expression of the genes. Igf2 and H19 genes are activated by the shared downstream enhancer, and their activations are dependent on the DNA methylation of the ICR. CCCTC binding factor (CTCF) is recruited to unmethylated ICR on the maternal allele that promotes the enhancer to activate the expression of $H 19$ gene, but not of Igf2 gene. In contract, on paternal allele, ICR is hypermethylated that prevents the binding of CTCF to ICR. The overall outcomes are that the expression of $H 19$ is repressed, but the expression of Igf2 is induced, from the paternal allele.

Most studies indicated that overexpression of H19 is associated with tumorigenesis (Table 1). Recent meta-analyses showed that the genetic variants of H19 (e.g., allele rs2839698) exhibited a significantly higher risk of developing cancer [128]. Poor overall survival could be predicted by high levels of H19 expression $[129,130]$. Therefore, H19 was proposed to serve as a biomarker for poor prognosis in various cancers with different types of predictive factors and clinicopathological features [130]. Moreover, the inhibition of H19 represents a potential candidate for cancer therapies [131].

Two major mechanisms of H19 in cancers were proposed. Firstly, H19 is a developmental reservoir of miR-675 that suppresses the expression of many tumor suppressors [125,132] (Table 3). Secondly, H19 functions as a modulator by binding directly to microRNAs (miRNAs) or proteins [125]. H19 acts as a molecular sponge to modulate the availability of miRNAs such as let-7 [133,134]. Let-7 was first identified as a key developmental regulator in nematode. The sequences of let-7 are highly conserved across species. Based on their expressions during developmental processes in vertebrates, let-7 is 
one of the most abundant miRNAs in adult mammalian tissues and acts as a tumor suppressor by promoting termination of differentiation [135]. There is growing evidence that many human cancers have deregulated let-7 expression, and restoring the let-7 expression may be a useful therapeutic approach in cancers [136]. Interestingly, a recent study demonstrated that let-7 also regulates H19 expression via the RNA-binding pluripotent stem cell factor LIN28 [137]. LIN28 is also a let-7 target and can drive tumor initiation and progression [138]. Intriguingly, LIN28 also blocks mature let-7 production [137]. By this negative feedback loop, breast cancer stem cell maintenance is promoted by H19/let-7/LIN28 axis [137].

Table 3. Targets of miR-675.

\begin{tabular}{cccc}
\hline Targeted mRNA & Targeted Region & Related Cancer or Diseases & References \\
\hline FADD & $3^{\prime}$-UTR & Gastric cancer & {$[139]$} \\
PTEN & $3^{\prime}$-UTR & Restenosis & {$[140]$} \\
Vitamin D receptor & $3^{\prime}$-UTR & Colon cancer & {$[141]$} \\
REPS2 & $3^{\prime}$-UTR & Esophageal squamous cell carcinoma & {$[142]$} \\
RUNX1 & 3'-UTR & Gastric cancer & {$[143]$} \\
TWIST1 & $3^{\prime}$-UTR & AFP-secreting hepatocellular carcinoma & {$[144]$} \\
Retinoblastoma & 3'-UTR & AFP-secreting hepatocellular carcinoma, & {$[144,145]$} \\
CALN1 & $3^{\prime}$-UTR & Colorectal cancer, glioma & {$[146]$} \\
c-Cbl & coding sequence & Gastric cancer & {$[147]$} \\
Cbl-b & coding sequence & Breast cancer & {$[147]$} \\
TGFBI & $3^{\prime}$-UTR & Breast cancer & {$[148]$} \\
Cadherin 13 & $3^{\prime}$-UTR & Prostate cancer & {$[149]$} \\
\hline
\end{tabular}

Abbreviations: 3'UTR: 3' untranslated region; AFP: $\alpha$-fetoprotein.

Previous studies have demonstrated that the LIN28/let-7 axis regulates glucose metabolism [150-152]. In brief, to upregulate the bioenergetic state of cells, glucose uptake and increasing the activities of both glycolysis and mitochondrial oxidative phosphorylation can be enhanced by reactivation of LIN28 and suppression of let-7 [138]. In addition, a recent study demonstrated that the expression of $\mathrm{H} 19$ is regulated by let-7, which is important for the muscle glucose metabolism [153]. As mentioned above, H19 is uniquely and highly expressed in muscle at all the studied ages. Therefore, exploring the physiological function of H19 in muscle will be of fundamental importance to various human diseases. Depletion of H19 impaired insulin sensitivity of muscle cells, which correlates with impaired glucose homeostasis in human and mouse [153].

Besides binding to miRNAs, H19 RNA also interacts with proteins. For example, H19 binds to hnRNP U, disrupts the hnRNP U-actin complex, and hence inhibits RNA Pol II-mediated transcription $[154,155]$. Blocking the interaction of hnRNP $U$ and actin was proposed to have a crucial effect on the fetal liver development [84]. In addition, H19 can alter the tumor suppressor miR-200 by increasing histone acetylation via the association with the protein complex hnRNP U/PCAF/RNAPol II [156].

Differentially methylated and imprinted control regions were found in the H19 promotor [157]. Methylation of the H19 promoter is negatively correlated with H19 expression. Under normal circumstances, in the offspring cell, the paternal copy of H19 is methylated and silent, but the maternal copy is hypomethylated or unmethylated and expressed [158]. In addition, like many other imprinted control genes, epidemiologic studies have demonstrated associations between environmental exposures and the expression of H19 [159]. To show the potential effects of maternal and paternal pre-conceptional over-nutrition, newborns of obese parents who have altered DNA methylation patterns at imprinted genes were reported recently [160]. The methylation percentages in a differentially methylated region (DMR) of H19 may be associated with childhood obesity in children [161,162]. Increased expression of H19 and miR-675, as well as altered methylation of the H19 imprinting control region, are associated with a low fat-free mass index in patients with chronic obstructive pulmonary disease [163]. The association among the altered methylation of the 
H19 imprinting control region and H19/miR-675 expression in obesity-induced cancers remains to be explored.

\subsection{HOTAIR}

HOTAIR (HOX transcript antisense RNA) is a $~ 2.2 \mathrm{~kb}$ nucleotide-long lncRNA, which transcribed in an antisense manner with respect to the HOXC genes, located on chromosome 12 [164]. HOX genes encode for regulatory transcription factors during embryogenesis [165]. Previous studies have demonstrated that HOX gene products also play significant roles in the development of cancers [166]. Numerous antisense lncRNAs regulate the associated protein coding genes in cis manner. However, although HOTAIR gene is encoded in the antisense-strand of HOXC genes, there is evidence that supports the fact that HOTAIR does not affect the expression of genes at the HOXC locus [167]. Similar to ANRIL, HOTAIR can affect chromatin state by interacting with PRC2 [168]. Alternatively, HOTAIR can repress the expression of genes at HOXD cluster via PRC2 complex [167,169]. HOTAIR is suggested to be a potential oncogene and is expressed in cancerous tissues higher than non-cancerous tissues (Table 1). It has been shown to have a significant impact on the tumor cell viability, proliferation, and invasion [168]. As its expression can be used to predict the metastatic progression and overall survival, HOTAIR was proposed as a prognostic biomarker in different types of cancers $[170,171]$.

It is generally believed that the global obesity pandemic is mainly a result of the high-caloric food and sedentary lifestyle [172]. A recent study demonstrated that a sedentary lifestyle further increases circulating exosomal HOTAIR in obese subjects, but not in lean subjects [173]. HOTAIR was expressed in gluteal adipose and a large increase in HOTAIR expression could induce differentiation in abdominal preadipocytes [174]. Scanning electron microscope (SEM) analysis further demonstrated that the gluteal adipose tissue was active in exosome biogenesis and secretion [173]. The induction of HOTAIR expression in gluteal fat upon squeeze is transcriptionally regulated via NFKB [173]. The same research team also found that sedentary lifestyle promoted gluteal-femoral fat to secrete exosomal HOTAIR that promotes intestinal cell proliferation [173]. Sedentary behavior increases the risk of certain cancers $[175,176]$. This study proposed a possible explanation for the linkage between obesity, sedentary lifestyle, and colorectal cancers via lncRNA HOTAIR. It is worthy to further explore whether sedentary lifestyle-induced exosomal HOTAIR from adipose tissues also promotes other obesity-related cancers.

\section{Conclusions}

A large number of epidemiological and mechanistic studies link obesity to the increased risk of and acceleration of the progression of several types of cancer. New hypotheses, such as kynurenine pathway implicated in both obesity and cancer, were proposed. In this review, we have briefly summarized the recent evidence to explore the potential contribution of three well-characterized oncogenic lncRNAs to obesity-induced cancers. The evidence shown here is mainly based on correlation and additional in vivo studies. Many oncogenic lncRNAs have been identified in recent years. Whether their expression level can be also regulated by nutrient availability and obese-related physiological changes remains to be investigated. In addition to the association studies, further genetic manipulation and in vivo evaluation are required to verify the actual functions and molecular mechanisms of those lncRNAs (Figure 2). As the expression of lncRNAs affected by epigenetic alterations are potentially reversible changes, these findings will offer attractive and promising strategies for therapeutic intervention. 


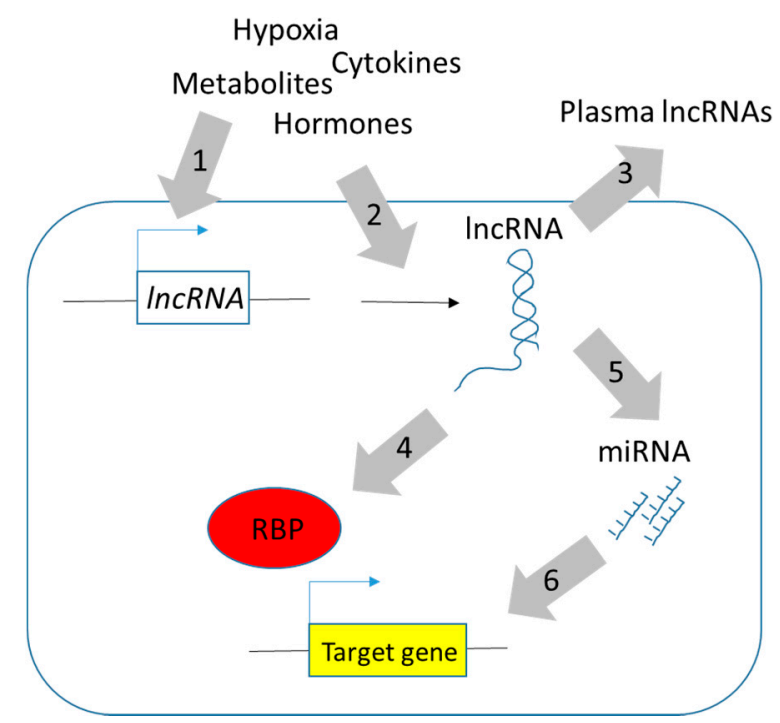

Figure 2. Proposed roles of long non-coding RNAs (lncRNAs) in obese-induced cancers. Many obese-related physiological changes such as nutrient availability, oxygen level, inflammatory cytokines, and metabolic hormones may affect the expression level (1) and post-transcriptional processing (2) of endogenous lncRNAs. Many lncRNAs can be transported to circulation and may serve as biomarkers or molecular diagnostic applications (3). Whether or not the exogenous lncRNAs contribute to the cancer progression is just emerging. In contrast, there is plentiful evidence showing that endogenous lncRNAs can regulate gene expression by diverse mechanisms. IncRNAs may act as scaffolds or molecular decoys, which directly interact with RNA binding proteins (RBPs; red circle) such as transcription factors and chromatin-modifying complexes to regulate the expression of proto-oncogenes and/or tumor suppressor genes (4). lncRNAs may act as endogenous sponges regulating gene expression via modulating microRNAs (miRNAs) availability (5 and 6).

Author Contributions: M.Y.-C.Y., L.X., C.-L.H. and C.-M.W. designed and wrote the review.

Funding: This work was supported by funding from The Hong Kong Polytechnic University (Internal grant 1.55.XX.99ZK and SFHMRF1718 to C.M.W.).

Acknowledgments: We thank colleagues who assisted with the initial writing, but whose work was not included in this review. C.M.W. also acknowledge the funding provided by The Hong Kong Polytechnic University.

Conflicts of Interest: The authors declare no conflict of interest.

\section{Abbreviations}

3'UTR

AFP

ANRIL

DMR

HOTAIR

HOX

IGF-1

lncRNAs

LPS

PRC2

RNA Pol II $3^{\prime}$ untranslated region

$\alpha$-fetoprotein

antisense non-coding RNA in the INK4 Locus

differentially methylated region

HOX transcript antisense RNA

Homebox

insulin-like growth factor-1

long noncoding RNAs

lipopolysaccharides

polycomb repressive complex-2

RNA polymerase II 


\section{References}

1. Tahergorabi, Z.; Khazaei, M.; Moodi, M.; Chamani, E. From obesity to cancer: A review on proposed mechanisms. Cell Biochem. Funct. 2016, 34, 533-545. [CrossRef] [PubMed]

2. Krishna, S.G.; Hussan, H.; Cruz-Monserrate, Z.; Conteh, L.F.; Mumtaz, K.; Conwell, D.L. A review of the impact of obesity on common gastrointestinal malignancies. Integr. Cancer Sci. Ther. 2017, 4. [CrossRef] [PubMed]

3. Majumder, K.; Gupta, A.; Arora, N.; Singh, P.P.; Singh, S. Premorbid obesity and mortality in patients with pancreatic cancer: A systematic review and meta-analysis. Clin. Gastroenterol. Hepatol. 2016, 14, 355-368. [CrossRef] [PubMed]

4. De Pergola, G.; Silvestris, F. Obesity as a major risk factor for cancer. J. Obes. 2013, 2013. [CrossRef] [PubMed]

5. Demark-Wahnefried, W.; Platz, E.A.; Ligibel, J.A.; Blair, C.K.; Courneya, K.S.; Meyerhardt, J.A.; Ganz, P.A.; Rock, C.L.; Schmitz, K.H.; Wadden, T.; et al. The role of obesity in cancer survival and recurrence. Cancer Epidemiol. Biomark. Prev. 2012, 21, 1244-1259. [CrossRef] [PubMed]

6. Roberts, D.L.; Dive, C.; Renehan, A.G. Biological mechanisms linking obesity and cancer risk: New perspectives. Annu. Rev. Med. 2010, 61, 301-316. [CrossRef] [PubMed]

7. Louie, S.M.; Roberts, L.S.; Nomura, D.K. Mechanisms linking obesity and cancer. Biochim. Biophys. Acta 2013, 1831, 1499-1508. [CrossRef] [PubMed]

8. Stone, T.W.; McPherson, M.; Gail Darlington, L. Obesity and cancer: Existing and new hypotheses for a causal connection. EBioMedicine 2018, 30, 14-28. [CrossRef] [PubMed]

9. Conte, C.; Fabbrini, E.; Kars, M.; Mittendorfer, B.; Patterson, B.W.; Klein, S. Multiorgan insulin sensitivity in lean and obese subjects. Diabetes Care 2012, 35, 1316-1321. [CrossRef] [PubMed]

10. Djiogue, S.; Nwabo Kamdje, A.H.; Vecchio, L.; Kipanyula, M.J.; Farahna, M.; Aldebasi, Y.; Seke Etet, P.F. Insulin resistance and cancer: The role of insulin and IGFs. Endocr Relat Cancer 2013, 20, R1-R17. [CrossRef] [PubMed]

11. Gallagher, E.J.; LeRoith, D. The proliferating role of insulin and insulin-like growth factors in cancer. Trends Endocrinol. Metab. 2010, 21, 610-618. [CrossRef] [PubMed]

12. Denduluri, S.K.; Idowu, O.; Wang, Z.; Liao, Z.; Yan, Z.; Mohammed, M.K.; Ye, J.; Wei, Q.; Wang, J.; Zhao, L.; et al. Insulin-like growth factor (IGF) signaling in tumorigenesis and the development of cancer drug resistance. Genes Dis. 2015, 2, 13-25. [CrossRef] [PubMed]

13. Frasca, F.; Pandini, G.; Sciacca, L.; Pezzino, V.; Squatrito, S.; Belfiore, A.; Vigneri, R. The role of insulin receptors and IGF-I receptors in cancer and other diseases. Arch. Physiol. Biochem. 2008, 114, $23-37$. [CrossRef] [PubMed]

14. Choe, S.S.; Huh, J.Y.; Hwang, I.J.; Kim, J.I.; Kim, J.B. Adipose tissue remodeling: its role in energy metabolism and metabolic disorders. Front. Endocrinol. 2016, 7. [CrossRef] [PubMed]

15. Coelho, M.; Oliveira, T.; Fernandes, R. Biochemistry of adipose tissue: An endocrine organ. Arch. Med. Sci. 2013, 9, 191-200. [CrossRef] [PubMed]

16. Feve, B.; Bastard, C.; Fellahi, S.; Bastard, J.P.; Capeau, J. New adipokines. Ann. D'endocrinol. 2016, 77, 49-56. [CrossRef] [PubMed]

17. Martyniak, K.; Masternak, M.M. Changes in adipose tissue cellular composition during obesity and aging as a cause of metabolic dysregulation. Exp. Gerontol. 2017, 94, 59-63. [CrossRef] [PubMed]

18. Balistreri, C.R.; Caruso, C.; Candore, G. The role of adipose tissue and adipokines in obesity-related inflammatory diseases. Mediat. Inflamm. 2010, 2010. [CrossRef] [PubMed]

19. Dutta, D.; Ghosh, S.; Pandit, K.; Mukhopadhyay, P.; Chowdhury, S. Leptin and cancer: Pathogenesis and modulation. Indian J. Endocrinol. Metab. 2012, 16 (Suppl. 3), S596-S600. [PubMed]

20. Cleary, M.P.; Torroella-Kouri, M. Leptin in cancer: Epidemiology and mechanisms. In Adipocytokines, Energy Balance, and Cancer; Reizes, O., Berger, N.A., Eds.; Springer International Publishing: Cham, Switzerland, 2017.

21. Hosney, M.; Sabet, S.; El-Shinawi, M.; Gaafar, K.M.; Mohamed, M.M. Leptin is overexpressed in the tumor microenvironment of obese patients with estrogen receptor positive breast cancer. Exp. Ther. Med. 2017, 13, 2235-2246. [CrossRef] [PubMed]

22. Candelaria, P.V.; Rampoldi, A.; Harbuzariu, A.; Gonzalez-Perez, R.R. Leptin signaling and cancer chemoresistance: Perspectives. World J. Clin. Oncol. 2017, 8, 106-119. [CrossRef] [PubMed] 
23. Sun, K.; Kusminski, C.M.; Scherer, P.E. Adipose tissue remodeling and obesity. J. Clin. Investig. 2011, 121, 2094-2101. [CrossRef] [PubMed]

24. Trayhurn, P. Hypoxia and adipose tissue function and dysfunction in obesity. Physiol. Rev. 2013, 93, 1-21. [CrossRef] [PubMed]

25. Balamurugan, K. HIF-1 at the crossroads of hypoxia, inflammation, and cancer. Int. J. Cancer. J. Int. Cancer 2016, 138, 1058-1066. [CrossRef] [PubMed]

26. Masoud, G.N.; Li, W. HIF-1 $\alpha$ pathway: Role, regulation and intervention for cancer therapy. Acta Pharm. Sin. B 2015, 5, 378-389. [CrossRef] [PubMed]

27. Agani, F.; Jiang, B.H. Oxygen-independent regulation of HIF-1: Novel involvement of PI3K/AKT/mTOR pathway in cancer. Curr. Cancer Drug Targets 2013, 13, 245-251. [CrossRef] [PubMed]

28. Soni, S.; Padwad, Y.S. HIF-1 in cancer therapy: Two decade long story of a transcription factor. Acta Oncol. 2017, 56, 503-515. [CrossRef] [PubMed]

29. He, Q.; Gao, Z.; Yin, J.; Zhang, J.; Yun, Z.; Ye, J. Regulation of HIF-1 $\alpha$ activity in adipose tissue by obesity-associated factors: Adipogenesis, insulin, and hypoxia. Am. J. Physiol. Endocrinol. Metab. 2011, 300, E877-E885. [CrossRef] [PubMed]

30. Rausch, L.K.; Netzer, N.C.; Hoegel, J.; Pramsohler, S. The linkage between breast cancer, hypoxia, and adipose tissue. Front. Oncol. 2017, 7. [CrossRef] [PubMed]

31. Grivennikov, S.I.; Greten, F.R.; Karin, M. Immunity, inflammation, and cancer. Cell 2010, 140, 883-899. [CrossRef] [PubMed]

32. De Marzo, A.M.; Platz, E.A.; Sutcliffe, S.; Xu, J.; Gronberg, H.; Drake, C.G.; Nakai, Y.; Isaacs, W.B.; Nelson, W.G. Inflammation in prostate carcinogenesis. Nat. Rev. Cancer 2007, 7, 256-269. [CrossRef] [PubMed]

33. Kawanishi, S.; Ohnishi, S.; Ma, N.; Hiraku, Y.; Murata, M. Crosstalk between DNA damage and inflammation in the multiple steps of carcinogenesis. Int. J. Mol. Sci. 2017, 18, 1808. [CrossRef] [PubMed]

34. Ouchi, N.; Parker, J.L.; Lugus, J.J.; Walsh, K. Adipokines in inflammation and metabolic disease. Nat. Rev. Immunol. 2011, 11, 85-97. [CrossRef] [PubMed]

35. Kern, P.A.; Di Gregorio, G.B.; Lu, T.; Rassouli, N.; Ranganathan, G. Adiponectin expression from human adipose tissue: Relation to obesity, insulin resistance, and tumor necrosis factor- $\alpha$ expression. Diabetes 2003, 52, 1779-1785. [CrossRef] [PubMed]

36. Mancuso, P. The role of adipokines in chronic inflammation. Immunotargets Ther. 2016, 5, 47-56. [CrossRef] [PubMed]

37. Boutagy, N.E.; McMillan, R.P.; Frisard, M.I.; Hulver, M.W. Metabolic endotoxemia with obesity: Is it real and is it relevant? Biochimie 2016, 124, 11-20. [CrossRef] [PubMed]

38. Jin, C.; Henao-Mejia, J.; Flavell, R.A. Innate immune receptors: Key regulators of metabolic disease progression. Cell Metab. 2013, 17, 873-882. [CrossRef] [PubMed]

39. Seganfredo, F.B.; Blume, C.A.; Moehlecke, M.; Giongo, A.; Casagrande, D.S.; Spolidoro, J.V.N.; Padoin, A.V.; Schaan, B.D.; Mottin, C.C. Weight-loss interventions and gut microbiota changes in overweight and obese patients: A systematic review. Obes. Rev. 2017, 18, 832-851. [CrossRef] [PubMed]

40. Berger, N.A.; Scacheri, P.C. Targeting epigenetics to prevent obesity promoted cancers. Cancer Prev. Res. 2018, 11, 125-128. [CrossRef] [PubMed]

41. Xu, X.; Su, S.; Barnes, V.A.; De Miguel, C.; Pollock, J.; Ownby, D.; Shi, H.; Zhu, H.; Snieder, H.; Wang, X. A genome-wide methylation study on obesity: Differential variability and differential methylation. Epigenetics 2013, 8, 522-533. [CrossRef] [PubMed]

42. Martinez, J.A.; Milagro, F.I.; Claycombe, K.J.; Schalinske, K.L. Epigenetics in adipose tissue, obesity, weight loss, and diabetes. Adv. Nutr. 2014, 5, 71-81. [CrossRef] [PubMed]

43. Sun, J.; Ruan, Y.; Wang, M.; Chen, R.; Yu, N.; Sun, L.; Liu, T.; Chen, H. Differentially expressed circulating lncRNAs and mRNA identified by microarray analysis in obese patients. Sci. Rep. 2016, 6. [CrossRef] [PubMed]

44. Latorre, J.; Fernandez-Real, J.M. lncRNAs in adipose tissue from obese and insulin-resistant subjects: New targets for therapy? EBioMedicine 2018, 30, 10-11. [CrossRef] [PubMed]

45. Chen, Z. Progress and prospects of long non-coding RNAs in lipid homeostasis. Mol. Metab. 2016, 5, 164-170. [CrossRef] [PubMed] 
46. Mi, L.; Zhao, X.Y.; Li, S.; Yang, G.; Lin, J.D. Conserved function of the long non-coding RNA Blnc1 in brown adipocyte differentiation. Mol. Metab. 2017, 6, 101-110. [CrossRef] [PubMed]

47. Karapetyan, A.R.; Buiting, C.; Kuiper, R.A.; Coolen, M.W. Regulatory roles for long ncRNA and mRNA. Cancers 2013, 5, 462-490. [CrossRef] [PubMed]

48. Dinger, M.E.; Pang, K.C.; Mercer, T.R.; Crowe, M.L.; Grimmond, S.M.; Mattick, J.S. NRED: A database of long non-coding RNA expression. Nucl. Acids Res. 2009, 37, D122-D126. [CrossRef] [PubMed]

49. Ji, Z.; Song, R.; Regev, A.; Struhl, K. Many lncRNAs, 5'UTRs, and pseudogenes are translated and some are likely to express functional proteins. Elife 2015, 4. [CrossRef] [PubMed]

50. Schmitt, A.M.; Chang, H.Y. Long non-coding RNAs in cancer pathways. Cancer Cell 2016, 29, $452-463$. [CrossRef] [PubMed]

51. Kung, J.T.; Colognori, D.; Lee, J.T. Long non-coding RNAs: Past, present, and future. Genetics 2013, 193, 651-669. [CrossRef] [PubMed]

52. Dykes, I.M.; Emanueli, C. Transcriptional and post-transcriptional gene regulation by long non-coding RNA. Genom. Proteom. Bioinform. 2017, 15, 177-186. [CrossRef] [PubMed]

53. Sun, X.; Haider Ali, M.S.S.; Moran, M. The role of interactions of long non-coding RNAs and heterogeneous nuclear ribonucleoproteins in regulating cellular functions. Biochem. J. 2017, 474, 2925-2935. [CrossRef] [PubMed]

54. Bolha, L.; Ravnik-Glavac, M.; Glavac, D. Long non-coding RNAs as biomarkers in cancer. Dis. Markers 2017, 2017. [CrossRef] [PubMed]

55. Sun, L.; Goff, L.A.; Trapnell, C.; Alexander, R.; Lo, K.A.; Hacisuleyman, E.; Sauvageau, M.; Tazon-Vega, B.; Kelley, D.R.; Hendrickson, D.G.; et al. Long non-coding RNAs regulate adipogenesis. Proc. Natl. Acad. Sci. USA 2013, 110, 3387-3392. [CrossRef] [PubMed]

56. Cheng, Y.; Gao, W.W.; Tang, H.M.; Deng, J.J.; Wong, C.M.; Chan, C.P.; Jin, D.Y. $\beta$-TrCP-mediated ubiquitination and degradation of liver-enriched transcription factor CREB-H. Sci. Rep. 2016, 6. [CrossRef] [PubMed]

57. Yang, L.; Li, P.; Yang, W.; Ruan, X.; Kiesewetter, K.; Zhu, J.; Cao, H. Integrative transcriptome analyses of metabolic responses in mice define pivotal lncrna metabolic regulators. Cell Metab. 2016, 24, 627-639. [CrossRef] [PubMed]

58. Nakaoka, H.; Gurumurthy, A.; Hayano, T.; Ahmadloo, S.; Omer, W.H.; Yoshihara, K.; Yamamoto, A.; Kurose, K.; Enomoto, T.; Akira, S.; et al. Allelic imbalance in regulation of ANRIL through chromatin interaction at 9p21 endometriosis risk locus. PLoS Genet. 2016, 12. [CrossRef] [PubMed]

59. Zhao, L.; Li, Z.; Chen, W.; Zhai, W.; Pan, J.; Pang, H.; Li, X. H19 promotes endometrial cancer progression by modulating epithelial-mesenchymal transition. Oncol. Lett. 2017, 13, 363-369. [CrossRef] [PubMed]

60. He, X.; Bao, W.; Li, X.; Chen, Z.; Che, Q.; Wang, H.; Wan, X.P. The long non-coding RNA HOTAIR is upregulated in endometrial carcinoma and correlates with poor prognosis. Int. J. Mol. Med. 2014, 33, 325-332. [CrossRef] [PubMed]

61. Zhou, Y.X.; Wang, C.; Mao, L.W.; Wang, Y.L.; Xia, L.Q.; Zhao, W.; Shen, J.; Chen, J. Long non-coding RNA HOTAIR mediates the estrogen-induced metastasis of endometrial cancer cells via the miR-646/NPM1 axis. Am. J. Physiol. Cell Physiol. 2018, 314, C690-C701. [CrossRef] [PubMed]

62. Chen, D.; Zhang, Z.; Mao, C.; Zhou, Y.; Yu, L.; Yin, Y.; Wu, S.; Mou, X.; Zhu, Y. ANRIL inhibits p15(INK4b) through the TGF $\beta 1$ signaling pathway in human esophageal squamous cell carcinoma. Cell. Immunol. 2014, 289, 91-96. [CrossRef] [PubMed]

63. Tan, D.; Wu, Y.; Hu, L.; He, P.; Xiong, G.; Bai, Y.; Yang, K. Long non-coding RNA H19 is up-regulated in esophageal squamous cell carcinoma and promotes cell proliferation and metastasis. Dis. Esophagus 2017, 30, 1-9. [PubMed]

64. Hibi, K.; Nakamura, H.; Hirai, A.; Fujikake, Y.; Kasai, Y.; Akiyama, S.; Ito, K.; Takagi, H. Loss of H19 imprinting in esophageal cancer. Cancer Res. 1996, 56, 480-482. [PubMed]

65. Wang, W.; He, X.; Zheng, Z.; Ma, X.; Hu, X.; Wu, D.; Wang, M. Serum HOTAIR as a novel diagnostic biomarker for esophageal squamous cell carcinoma. Mol. Cancer 2017, 16. [CrossRef] [PubMed]

66. Lv, X.B.; Lian, G.Y.; Wang, H.R.; Song, E.; Yao, H.; Wang, M.H. Long non-coding RNA HOTAIR is a prognostic marker for esophageal squamous cell carcinoma progression and survival. PLoS ONE 2013, 8. [CrossRef] [PubMed] 
67. Huang, M.D.; Chen, W.M.; Qi, F.Z.; Xia, R.; Sun, M.; Xu, T.P.; Yin, L.; Zhang, E.B.; De, W.; Shu, Y.Q. Long non-coding RNA ANRIL is upregulated in hepatocellular carcinoma and regulates cell apoptosis by epigenetic silencing of KLF2. J. Hematol. Oncol. 2015, 8. [CrossRef] [PubMed]

68. Hua, L.; Wang, C.Y.; Yao, K.H.; Chen, J.T.; Zhang, J.J.; Ma, W.L. High expression of long non-coding RNA ANRIL is associated with poor prognosis in hepatocellular carcinoma. Int. J. Clin. Exp. Pathol. 2015, 8, 3076-3082. [PubMed]

69. Fellig, Y.; Ariel, I.; Ohana, P.; Schachter, P.; Sinelnikov, I.; Birman, T.; Ayesh, S.; Schneider, T.; de Groot, N.; Czerniak, A.; et al. H19 expression in hepatic metastases from a range of human carcinomas. J. Clin. Pathol. 2005, 58, 1064-1068. [CrossRef] [PubMed]

70. Yang, Z.; Lu, Y.; Xu, Q.; Tang, B.; Park, C.K.; Chen, X. HULC and H19 played different roles in overall and disease-free survival from hepatocellular carcinoma after curative hepatectomy: A preliminary analysis from gene expression omnibus. Dis. Markers 2015, 2015. [CrossRef] [PubMed]

71. Wang, L.P.; Wang, J.P.; Wang, X.P. HOTAIR contributes to the growth of liver cancer via targeting miR-217. Oncol. Lett. 2018, 15, 7963-7972. [CrossRef] [PubMed]

72. Chen, S.; Zhang, J.Q.; Chen, J.Z.; Chen, H.X.; Qiu, F.N.; Yan, M.L.; Chen, Y.L.; Peng, C.H.; Tian, Y.F.; Wang, Y.D. The over expression of long non-coding RNA ANRIL promotes epithelial-mesenchymal transition by activating the ATM-E2F1 signaling pathway in pancreatic cancer: An in vivo and in vitro study. Int. J. Biol. Macromol. 2017, 102, 718-728. [CrossRef] [PubMed]

73. Zhao, B.; Lu, Y.L.; Yang, Y.; Hu, L.B.; Bai, Y.; Li, R.Q.; Zhang, G.Y.; Li, J.; Bi, C.W.; Yang, L.B.; et al. Overexpression of lncRNA ANRIL promoted the proliferation and migration of prostate cancer cells via regulating let-7a/TGF- $\beta 1 /$ Smad signaling pathway. Cancer Biomark. 2018, 21, 613-620. [CrossRef] [PubMed]

74. Ma, C.; Nong, K.; Zhu, H.; Wang, W.; Huang, X.; Yuan, Z.; Ai, K. H19 promotes pancreatic cancer metastasis by derepressing let-7's suppression on its target HMGA2-mediated EMT. Tumour Biol. 2014, 35, 9163-9169. [CrossRef] [PubMed]

75. Cai, H.; Yao, J.; An, Y.; Chen, X.; Chen, W.; Wu, D.; Luo, B.; Yang, Y.; Jiang, Y.; Sun, D.; et al. lncRNA HOTAIR acts a competing endogenous RNA to control the expression of Notch3 via sponging miR-613 in pancreatic cancer. Oncotarget 2017, 8, 32905-32917. [CrossRef] [PubMed]

76. Kim, K.; Jutooru, I.; Chadalapaka, G.; Johnson, G.; Frank, J.; Burghardt, R.; Kim, S.; Safe, S. HOTAIR is a negative prognostic factor and exhibits pro-oncogenic activity in pancreatic cancer. Oncogene 2013, 32, 1616-1625. [CrossRef] [PubMed]

77. Sun, Y.; Zheng, Z.P.; Li, H.; Zhang, H.Q.; Ma, F.Q. ANRIL is associated with the survival rate of patients with colorectal cancer, and affects cell migration and invasion in vitro. Mol. Med. Rep. 2016, 14, 1714-1720. [CrossRef] [PubMed]

78. Sun, Z.; Ou, C.; Ren, W.; Xie, X.; Li, X.; Li, G. Downregulation of long non-coding RNA ANRIL suppresses lymphangiogenesis and lymphatic metastasis in colorectal cancer. Oncotarget 2016, 7, 47536-47555. [CrossRef] [PubMed]

79. Yang, Q.; Wang, X.; Tang, C.; Chen, X.; He, J. H19 promotes the migration and invasion of colon cancer by sponging miR-138 to upregulate the expression of HMGA1. Int. J. Oncol. 2017, 50, 1801-1809. [CrossRef] [PubMed]

80. Schultheiss, C.S.; Laggai, S.; Czepukojc, B.; Hussein, U.K.; List, M.; Barghash, A.; Tierling, S.; Hosseini, K.; Golob-Schwarzl, N.; Pokorny, J.; et al. The long non-coding RNA H19 suppresses carcinogenesis and chemoresistance in hepatocellular carcinoma. Cell Stress 2018, 1, 37-54. [CrossRef]

81. Li, P.; Zhang, X.; Wang, L.; Du, L.; Yang, Y.; Liu, T.; Li, C.; Wang, C. lncRNA HOTAIR contributes to 5FU resistance through suppressing miR-218 and activating NF- $\mathrm{BB} / \mathrm{TS}$ signaling in colorectal cancer. Mol. Ther. Nucl. Acids 2017, 8, 356-369. [CrossRef] [PubMed]

82. Lu, X.; Liu, Z.; Ning, X.; Huang, L.; Jiang, B. The long non-coding RNA HOTAIR promotes colorectal cancer progression by sponging miR-197. Oncol. Res. 2017. [CrossRef] [PubMed]

83. Liu, B.; Shen, E.D.; Liao, M.M.; Hu, Y.B.; Wu, K.; Yang, P.; Zhou, L.; Chen, W.D. Expression and mechanisms of long non-coding RNA genes MEG3 and ANRIL in gallbladder cancer. Tumour Biol. 2016, 37, 9875-9886. [CrossRef] [PubMed]

84. Wang, S.; Wu, X.; Liu, Y.; Yuan, J.; Yang, F.; Huang, J.; Meng, Q.; Zhou, C.; Liu, F.; Ma, J.; et al. Long non-coding RNA H19 inhibits the proliferation of fetal liver cells and the Wnt signaling pathway. FEBS Lett. 2016, 590, 559-570. [CrossRef] [PubMed] 
85. Wang, S.H.; Wu, X.C.; Zhang, M.D.; Weng, M.Z.; Zhou, D.; Quan, Z.W. Upregulation of H19 indicates a poor prognosis in gallbladder carcinoma and promotes epithelial-mesenchymal transition. Am. J. Cancer Res. 2016, 6, 15-26. [PubMed]

86. Ma, M.Z.; Li, C.X.; Zhang, Y.; Weng, M.Z.; Zhang, M.D.; Qin, Y.Y.; Gong, W.; Quan, Z.W. Long non-coding RNA HOTAIR, a c-Myc activated driver of malignancy, negatively regulates miRNA-130a in gallbladder cancer. Mol. Cancer 2014, 13. [CrossRef] [PubMed]

87. Xu, S.T.; Xu, J.H.; Zheng, Z.R.; Zhao, Q.Q.; Zeng, X.S.; Cheng, S.X.; Liang, Y.H.; Hu, Q.F. Long non-coding RNA ANRIL promotes carcinogenesis via sponging miR-199a in triple-negative breast cancer. Biomed. Pharmacother. Biomed. Pharmacother. 2017, 96, 14-21. [CrossRef] [PubMed]

88. Adriaenssens, E.; Dumont, L.; Lottin, S.; Bolle, D.; Lepretre, A.; Delobelle, A.; Bouali, F.; Dugimont, T.; Coll, J.; Curgy, J.J. H19 overexpression in breast adenocarcinoma stromal cells is associated with tumor values and steroid receptor status but independent of p53 and Ki-67 expression. Am. J. Pathol. 1998, 153, 1597-1607. [CrossRef]

89. Ding, W.; Ren, J.; Ren, H.; Wang, D. Long non-coding RNA HOTAIR modulates miR-206-mediated Bcl-w signaling to facilitate cell proliferation in breast cancer. Sci. Rep. 2017, 7. [CrossRef] [PubMed]

90. Qiu, J.J.; Lin, Y.Y.; Ding, J.X.; Feng, W.W.; Jin, H.Y.; Hua, K.Q. Long non-coding RNA ANRIL predicts poor prognosis and promotes invasion/metastasis in serous ovarian cancer. Int. J. Oncol. 2015, 46, 2497-2505. [CrossRef] [PubMed]

91. Zhu, Z.; Song, L.; He, J.; Sun, Y.; Liu, X.; Zou, X. Ectopic expressed long non-coding RNA H19 contributes to malignant cell behavior of ovarian cancer. Int. J. Clin. Exp. Pathol. 2015, 8, 10082-10091. [PubMed]

92. Liu, S.; Lei, H.; Luo, F.; Li, Y.; Xie, L. The effect of lncRNA HOTAIR on chemoresistance of ovarian cancer through regulation of HOXA7. Biol. Chem. 2018, 399, 485-497. [CrossRef] [PubMed]

93. Zhao, J.J.; Hao, S.; Wang, L.L.; Hu, C.Y.; Zhang, S.; Guo, L.J.; Zhang, G.; Gao, B.; Jiang, Y.; Tian, W.G.; et al. Long non-coding RNA ANRIL promotes the invasion and metastasis of thyroid cancer cells through TGF- $\beta$ /Smad signaling pathway. Oncotarget 2016, 7, 57903-57918. [CrossRef] [PubMed]

94. Lan, X.; Sun, W.; Dong, W.; Wang, Z.; Zhang, T.; He, L.; Zhang, H. Downregulation of long non-coding RNA H19 contributes to the proliferation and migration of papillary thyroid carcinoma. Gene 2018, 646, 98-105. [CrossRef] [PubMed]

95. Zhang, Y.; Yu, S.; Jiang, L.; Wang, X.; Song, X. HOTAIR is a promising novel biomarker in patients with thyroid cancer. Exp. Ther. Med. 2017, 13, 2274-2278. [CrossRef] [PubMed]

96. Di, W.; Li, Q.; Shen, W.; Guo, H.; Zhao, S. The long non-coding RNA HOTAIR promotes thyroid cancer cell growth, invasion and migration through the miR-1-CCND2 axis. Am. J. Cancer Res. 2017, 7, 1298-1309. [PubMed]

97. Congrains, A.; Kamide, K.; Ohishi, M.; Rakugi, H. ANRIL: Molecular mechanisms and implications in human health. Int. J. Mol. Sci. 2013, 14, 1278-1292. [CrossRef] [PubMed]

98. Sherr, C.J. Ink4-Arf locus in cancer and aging. Wiley Interdiscip. Rev. Dev. Biol. 2012, 1, 731-741. [CrossRef] [PubMed]

99. Kotake, Y.; Nakagawa, T.; Kitagawa, K.; Suzuki, S.; Liu, N.; Kitagawa, M.; Xiong, Y. Long non-coding RNA ANRIL is required for the PRC2 recruitment to and silencing of p15(INK4B) tumor suppressor gene. Oncogene 2011, 30, 1956-1962. [CrossRef] [PubMed]

100. Pasmant, E.; Laurendeau, I.; Heron, D.; Vidaud, M.; Vidaud, D.; Bieche, I. Characterization of a germ-line deletion, including the entire INK4/ARF locus, in a melanoma-neural system tumor family: identification of ANRIL, an antisense noncoding RNA whose expression coclusters with ARF. Cancer Res. 2007, 67, 3963-3969. [CrossRef] [PubMed]

101. Li, Z.; Yu, X.; Shen, J. ANRIL: A pivotal tumor suppressor long non-coding RNA in human cancers. Tumour Biol. 2016, 37, 5657-5661. [CrossRef] [PubMed]

102. Wan, G.; Mathur, R.; Hu, X.; Liu, Y.; Zhang, X.; Peng, G.; Lu, X. Long non-coding RNA ANRIL (CDKN2B-AS) is induced by the ATM-E2F1 signaling pathway. Cell. Signal. 2013, 25, 1086-1095. [CrossRef] [PubMed]

103. Rodriguez, C.; Borgel, J.; Court, F.; Cathala, G.; Forne, T.; Piette, J. CTCF is a DNA methylation-sensitive positive regulator of the INK/ARF locus. Biochem. Biophys. Res. Commun. 2010, 392, 129-134. [CrossRef] [PubMed] 
104. Wang, H.; Maurano, M.T.; Qu, H.; Varley, K.E.; Gertz, J.; Pauli, F.; Lee, K.; Canfield, T.; Weaver, M.; Sandstrom, R.; et al. Widespread plasticity in CTCF occupancy linked to DNA methylation. Genome Res. 2012, 22, 1680-1688. [CrossRef] [PubMed]

105. Bell, A.C.; Felsenfeld, G. Methylation of a CTCF-dependent boundary controls imprinted expression of the Igf2 gene. Nature 2000, 405, 482-485. [CrossRef] [PubMed]

106. Cunnington, M.S.; Santibanez Koref, M.; Mayosi, B.M.; Burn, J.; Keavney, B. Chromosome 9p21 SNPs associated with multiple disease phenotypes correlate with ANRIL expression. PLoS Genet. 2010, 6. [CrossRef] [PubMed]

107. Kong, Y.; Sharma, R.B.; Nwosu, B.U.; Alonso, L.C. Islet biology, the CDKN2A/B locus and type 2 diabetes risk. Diabetologia 2016, 59, 1579-1593. [CrossRef] [PubMed]

108. Murray, R.; Bryant, J.; Titcombe, P.; Barton, S.J.; Inskip, H.; Harvey, N.C.; Cooper, C.; Lillycrop, K.; Hanson, M.; Godfrey, K.M. DNA methylation at birth within the promoter of ANRIL predicts markers of cardiovascular risk at 9 years. Clin. Epigenetics 2016, 8. [CrossRef] [PubMed]

109. Lillycrop, K.; Murray, R.; Cheong, C.; Teh, A.L.; Clarke-Harris, R.; Barton, S.; Costello, P.; Garratt, E.; Cook, E.; Titcombe, P.; et al. ANRIL promoter DNA methylation: A perinatal marker for later adiposity. EBioMedicine 2017, 19, 60-72. [CrossRef] [PubMed]

110. Helgadottir, A.; Thorleifsson, G.; Manolescu, A.; Gretarsdottir, S.; Blondal, T.; Jonasdottir, A.; Jonasdottir, A.; Sigurdsson, A.; Baker, A.; Palsson, A.; et al. A common variant on chromosome 9p21 affects the risk of myocardial infarction. Science 2007, 316, 1491-1493. [CrossRef] [PubMed]

111. Broadbent, H.M.; Peden, J.F.; Lorkowski, S.; Goel, A.; Ongen, H.; Green, F.; Clarke, R.; Collins, R.; Franzosi, M.G.; Tognoni, G.; et al. Susceptibility to coronary artery disease and diabetes is encoded by distinct, tightly linked SNPs in the ANRIL locus on chromosome 9p. Hum. Mol. Genet. 2008, 17, 806-814. [CrossRef] [PubMed]

112. Wei, F.; Cai, C.; Feng, S.; Lv, J.; Li, S.; Chang, B.; Zhang, H.; Shi, W.; Han, H.; Ling, C.; et al. TOX and $C D K N 2 A / B$ gene polymorphisms are associated with type 2 diabetes in Han Chinese. Sci. Rep. 2015, 5. [CrossRef] [PubMed]

113. Cheng, J.; Cai, M.Y.; Chen, Y.N.; Li, Z.C.; Tang, S.S.; Yang, X.L.; Chen, C.; Liu, X.; Xiong, X.D. Variants in ANRIL gene correlated with its expression contribute to myocardial infarction risk. Oncotarget 2017, 8 , 12607-12619. [CrossRef] [PubMed]

114. Mafi Golchin, M.; Ghaderian, S.M.H.; Akhavan-Niaki, H.; Jalalian, R.; Heidari, L.; Salami, S.A. Analysis of two CDKN2B-AS polymorphisms in relation to coronary artery disease patients in North of Iran. Int. J. Mol. Cell. Med. 2017, 6, 31-37. [PubMed]

115. Arbiol-Roca, A.; Padro-Miquel, A.; Hueso, M.; Navarro, E.; Alia-Ramos, P.; Gonzalez-Alvarez, M.T.; Rama, I.; Torras, J.; Grinyo, J.M.; Cruzado, J.M.; et al. Association of ANRIL gene polymorphisms with major adverse cardiovascular events in hemodialysis patients. Clin. Chim. Acta 2017, 466, 61-67. [CrossRef] [PubMed]

116. Kong, Y.; Sharma, R.B.; Ly, S.; Stamateris, R.E.; Jesdale, W.M.; Alonso, L.C. CDKN2A/B T2D genome-wide association study risk SNPs impact locus gene expression and proliferation in human islets. Diabetes 2018, 67, 872-884. [CrossRef] [PubMed]

117. Bochenek, G.; Hasler, R.; El Mokhtari, N.E.; Konig, I.R.; Loos, B.G.; Jepsen, S.; Rosenstiel, P.; Schreiber, S.; Schaefer, A.S. The large non-coding RNA ANRIL, which is associated with atherosclerosis, periodontitis and several forms of cancer, regulates ADIPOR1, VAMP3 and C11ORF10. Hum. Mol. Genet. 2013, 22, 4516-4527. [CrossRef] [PubMed]

118. Roux, B.T.; Heward, J.A.; Donnelly, L.E.; Jones, S.W.; Lindsay, M.A. Catalog of differentially expressed long non-coding RNA following activation of human and mouse innate immune response. Front. Immunol. 2017, 8. [CrossRef] [PubMed]

119. Chowdhury, I.H.; Narra, H.P.; Sahni, A.; Khanipov, K.; Schroeder, C.L.C.; Patel, J.; Fofanov, Y.; Sahni, S.K. Expression profiling of long non-coding RNA splice variants in human microvascular endothelial cells: Lipopolysaccharide effects in vitro. Med. Inflamm. 2017, 2017. [CrossRef] [PubMed]

120. Falls, J.G.; Pulford, D.J.; Wylie, A.A.; Jirtle, R.L. Genomic imprinting: Implications for human disease. Am. J. Pathol. 1999, 154, 635-647. [CrossRef]

121. Bartolomei, M.S.; Zemel, S.; Tilghman, S.M. Parental imprinting of the mouse H19 gene. Nature 1991, 351, 153-155. [CrossRef] [PubMed] 
122. Leibovitch, M.P.; Nguyen, V.C.; Gross, M.S.; Solhonne, B.; Leibovitch, S.A.; Bernheim, A. The human ASM (adult skeletal muscle) gene: Expression and chromosomal assignment to 11p15. Biochem. Biophys. Res. Commun. 1991, 180, 1241-1250. [CrossRef]

123. Sasaki, H.; Ishihara, K.; Kato, R. Mechanisms of Igf2/H19 imprinting: DNA methylation, chromatin and long-distance gene regulation. J. Biochem. 2000, 127, 711-715. [CrossRef] [PubMed]

124. Rainier, S.; Johnson, L.A.; Dobry, C.J.; Ping, A.J.; Grundy, P.E.; Feinberg, A.P. Relaxation of imprinted genes in human cancer. Nature 1993, 362, 747-749. [CrossRef] [PubMed]

125. Raveh, E.; Matouk, I.J.; Gilon, M.; Hochberg, A. The H19 long non-coding RNA in cancer initiation, progression and metastasis-A proposed unifying theory. Mol Cancer 2015, 14. [CrossRef] [PubMed]

126. Bauderlique-Le Roy, H.; Vennin, C.; Brocqueville, G.; Spruyt, N.; Adriaenssens, E.; Bourette, R.P. Enrichment of human stem-like prostate cells with s-SHIP promoter activity uncovers a role in stemness for the long noncoding RNA H19. Stem. Cells Dev. 2015, 24, 1252-1262. [CrossRef] [PubMed]

127. Shima, H.; Kida, K.; Adachi, S.; Yamada, A.; Sugae, S.; Narui, K.; Miyagi, Y.; Nishi, M.; Ryo, A.; Murata, S.; et al. lnc RNA H19 is associated with poor prognosis in breast cancer patients and promotes cancer stemness. Breast Cancer Res. Treat. 2018, 170, 507-516. [CrossRef] [PubMed]

128. Chu, M.; Yuan, W.; Wu, S.; Wang, Z.; Mao, L.; Tian, T.; Lu, Y.; Zhu, B.; Yang, Y.; Wang, B.; et al. Quantitative assessment of polymorphisms in H19 lncRNA and cancer risk: A meta-analysis of 13,392 cases and 18,893 controls. Oncotarget 2016, 7, 78631-78639. [CrossRef] [PubMed]

129. Chen, J.S.; Wang, Y.F.; Zhang, X.Q.; Lv, J.M.; Li, Y.; Liu, X.X.; Xu, T.P. H19 serves as a diagnostic biomarker and up-regulation of $H 19$ expression contributes to poor prognosis in patients with gastric cancer. Neoplasma 2016, 63, 223-230. [CrossRef] [PubMed]

130. Liu, F.T.; Pan, H.; Xia, G.F.; Qiu, C.; Zhu, Z.M. Prognostic and clinicopathological significance of long noncoding RNA H19 overexpression in human solid tumors: Evidence from a meta-analysis. Oncotarget 2016, 7, 83177-83186. [CrossRef] [PubMed]

131. Yoshimura, H.; Matsuda, Y.; Yamamoto, M.; Michishita, M.; Takahashi, K.; Sasaki, N.; Ishikawa, N.; Aida, J.; Takubo, K.; Arai, T.; et al. Reduced expression of the H19 long non-coding RNA inhibits pancreatic cancer metastasis. Lab. Investig. 2018, 98, 814-824. [CrossRef] [PubMed]

132. Keniry, A.; Oxley, D.; Monnier, P.; Kyba, M.; Dandolo, L.; Smits, G.; Reik, W. The H19 lincRNA is a developmental reservoir of miR-675 that suppresses growth and Igf1r. Nat. Cell Biol. 2012, 14, 659-665. [CrossRef] [PubMed]

133. Kallen, A.N.; Zhou, X.B.; Xu, J.; Qiao, C.; Ma, J.; Yan, L.; Lu, L.; Liu, C.; Yi, J.S.; Zhang, H.; et al. The imprinted H19 lncRNA antagonizes let-7 microRNAs. Mol. Cell 2013, 52, 101-112. [CrossRef] [PubMed]

134. Wei, Y.; Liu, Z.; Fang, J. H19 functions as a competing endogenous RNA to regulate human epidermal growth factor receptor expression by sequestering let7c in gastric cancer. Mol. Med. Rep. 2018, 17, 2600-2606. [PubMed]

135. Sun, X.; Liu, J.; Xu, C.; Tang, S.C.; Ren, H. The insights of Let-7 miRNAs in oncogenesis and stem cell potency. J. Cell. Mol. Med. 2016, 20, 1779-1788. [CrossRef] [PubMed]

136. Boyerinas, B.; Park, S.M.; Hau, A.; Murmann, A.E.; Peter, M.E. The role of let-7 in cell differentiation and cancer. Endocr. Relat. Cancer 2010, 17, F19-F36. [CrossRef] [PubMed]

137. Peng, F.; Li, T.T.; Wang, K.L.; Xiao, G.Q.; Wang, J.H.; Zhao, H.D.; Kang, Z.J.; Fan, W.J.; Zhu, L.L.; Li, M.; et al. H19/let-7/LIN28 reciprocal negative regulatory circuit promotes breast cancer stem cell maintenance. Cell Death Dis. 2017, 8. [CrossRef] [PubMed]

138. Nguyen, L.H.; Zhu, H. Lin28 and let-7 in cell metabolism and cancer. Transl. Pediatr. 2015, 4, 4-11. [PubMed]

139. Yan, J.; Zhang, Y.; She, Q.; Li, X.; Peng, L.; Wang, X.; Liu, S.; Shen, X.; Zhang, W.; Dong, Y.; et al. Long non-coding RNA H19/miR-675 axis promotes gastric cancer via FADD/Caspase 8/Caspase 3 signaling pathway. Cell. Physiol. Biochem. 2017, 42, 2364-2376. [CrossRef] [PubMed]

140. Lv, J.; Wang, L.; Zhang, J.; Lin, R.; Wang, L.; Sun, W.; Wu, H.; Xin, S. Long non-coding RNA H19-derived miR-675 aggravates restenosis by targeting PTEN. Biochem. Biophys. Res. Commun. 2018, 497, 1154-1161. [CrossRef] [PubMed]

141. Chen, S.; Bu, D.; Ma, Y.; Zhu, J.; Chen, G.; Sun, L.; Zuo, S.; Li, T.; Pan, Y.; Wang, X.; et al. H19 overexpression induces resistance to $1,25(\mathrm{OH}) 2 \mathrm{D} 3$ by targeting VDR through miR-675-5p in colon cancer cells. Neoplasia 2017, 19, 226-236. [CrossRef] [PubMed] 
142. Zhou, Y.W.; Zhang, H.; Duan, C.J.; Gao, Y.; Cheng, Y.D.; He, D.; Li, R.; Zhang, C.F. miR-675-5p enhances tumorigenesis and metastasis of esophageal squamous cell carcinoma by targeting REPS2. Oncotarget 2016, 7, 30730-30747. [CrossRef] [PubMed]

143. Zhuang, M.; Gao, W.; Xu, J.; Wang, P.; Shu, Y. The long non-coding RNA H19-derived miR-675 modulates human gastric cancer cell proliferation by targeting tumor suppressor RUNX1. Biochem. Biophys. Res. Commun. 2014, 448, 315-322. [CrossRef] [PubMed]

144. Hernandez, J.M.; Elahi, A.; Clark, C.W.; Wang, J.; Humphries, L.A.; Centeno, B.; Bloom, G.; Fuchs, B.C.; Yeatman, T.; Shibata, D. miR-675 mediates downregulation of Twist1 and Rb in AFP-secreting hepatocellular carcinoma. Ann. Surg. Oncol. 2013, 20 (Suppl. 3), S625-S635. [CrossRef] [PubMed]

145. Tsang, W.P.; Ng, E.K.; Ng, S.S.; Jin, H.; Yu, J.; Sung, J.J.; Kwok, T.T. Oncofetal H19-derived miR-675 regulates tumor suppressor RB in human colorectal cancer. Carcinogenesis 2010, 31, 350-358. [CrossRef] [PubMed]

146. Li, H.; Yu, B.; Li, J.; Su, L.; Yan, M.; Zhu, Z.; Liu, B. Overexpression of IncRNA H19 enhances carcinogenesis and metastasis of gastric cancer. Oncotarget 2014, 5, 2318-2329. [CrossRef] [PubMed]

147. Vennin, C.; Spruyt, N.; Dahmani, F.; Julien, S.; Bertucci, F.; Finetti, P.; Chassat, T.; Bourette, R.P.; Le Bourhis, X.; Adriaenssens, E. H19 non-coding RNA-derived miR-675 enhances tumorigenesis and metastasis of breast cancer cells by downregulating c-Cbl and Cbl-b. Oncotarget 2015, 6, 29209-29223. [CrossRef] [PubMed]

148. Zhu, M.; Chen, Q.; Liu, X.; Sun, Q.; Zhao, X.; Deng, R.; Wang, Y.; Huang, J.; Xu, M.; Yan, J.; et al. IncRNA H19/miR-675 axis represses prostate cancer metastasis by targeting TGFBI. FEBS J. 2014, 281, 3766-3775. [CrossRef] [PubMed]

149. Shi, Y.; Wang, Y.; Luan, W.; Wang, P.; Tao, T.; Zhang, J.; Qian, J.; Liu, N.; You, Y. Long non-coding RNA H19 promotes glioma cell invasion by deriving miR-675. PLoS ONE 2014, 9. [CrossRef] [PubMed]

150. Ma, X.; Li, C.; Sun, L.; Huang, D.; Li, T.; He, X.; Wu, G.; Yang, Z.; Zhong, X.; Song, L.; et al. Lin28/let-7 axis regulates aerobic glycolysis and cancer progression via PDK1. Nat. Commun. 2014, 5. [CrossRef] [PubMed]

151. Shyh-Chang, N.; Zhu, H.; Yvanka de Soysa, T.; Shinoda, G.; Seligson, M.T.; Tsanov, K.M.; Nguyen, L.; Asara, J.M.; Cantley, L.C.; Daley, G.Q. Lin28 enhances tissue repair by reprogramming cellular metabolism. Cell 2013, 155, 778-792. [CrossRef] [PubMed]

152. Zhu, H.; Shyh-Chang, N.; Segre, A.V.; Shinoda, G.; Shah, S.P.; Einhorn, W.S.; Takeuchi, A.; Engreitz, J.M.; Hagan, J.P.; Kharas, M.G.; et al. The Lin28/let-7 axis regulates glucose metabolism. Cell 2011, 147, 81-94. [CrossRef] [PubMed]

153. Gao, Y.; Wu, F.; Zhou, J.; Yan, L.; Jurczak, M.J.; Lee, H.Y.; Yang, L.; Mueller, M.; Zhou, X.B.; Dandolo, L.; et al. The H19/let-7 double-negative feedback loop contributes to glucose metabolism in muscle cells. Nucl. Acids Res. 2014, 42, 13799-13811. [CrossRef] [PubMed]

154. Han, N.; Li, W.; Zhang, M. The function of the RNA-binding protein hnRNP in cancer metastasis. J. Cancer Res. Ther. 2013, 9, S129-S134. [PubMed]

155. Bi, H.S.; Yang, X.Y.; Yuan, J.H.; Yang, F.; Xu, D.; Guo, Y.J.; Zhang, L.; Zhou, C.C.; Wang, F.; Sun, S.H. H19 inhibits RNA polymerase II-mediated transcription by disrupting the hnRNP U-actin complex. Biochim. Biophys. Acta 2013, 1830, 4899-4906. [CrossRef] [PubMed]

156. Zhang, L.; Yang, F.; Yuan, J.H.; Yuan, S.X.; Zhou, W.P.; Huo, X.S.; Xu, D.; Bi, H.S.; Wang, F.; Sun, S.H. Epigenetic activation of the miR-200 family contributes to H19-mediated metastasis suppression in hepatocellular carcinoma. Carcinogenesis 2013, 34, 577-586. [CrossRef] [PubMed]

157. Bartolomei, M.S.; Ferguson-Smith, A.C. Mammalian genomic imprinting. Cold Spring Harb. Perspect. Biol. 2011, 3. [CrossRef] [PubMed]

158. Kelsey, G.; Feil, R. New insights into establishment and maintenance of DNA methylation imprints in mammals. Philos. Trans. R. Soc. Lond. B Biol. Sci. 2013, 368. [CrossRef] [PubMed]

159. Rozek, L.S.; Dolinoy, D.C.; Sartor, M.A.; Omenn, G.S. Epigenetics: relevance and implications for public health. Annu. Rev. Public Health 2014, 35, 105-122. [CrossRef] [PubMed]

160. Khadilkar, A.V.; Sanwalka, N.J.; Chiplonkar, S.A.; Khadilkar, V.V.; Pandit, D. Body fat reference percentiles on healthy affluent Indian children and adolescents to screen for adiposity. Int. J. Obes. 2013, 37, 947-953. [CrossRef] [PubMed]

161. Hernandez-Valero, M.A.; Rother, J.; Gorlov, I.; Frazier, M.; Gorlova, O. Interplay between polymorphisms and methylation in the H19/IGF2 gene region may contribute to obesity in Mexican-American children. J. Dev. Orig. Health Dis. 2013, 4, 499-506. [CrossRef] [PubMed] 
162. Perkins, E.; Murphy, S.K.; Murtha, A.P.; Schildkraut, J.; Jirtle, R.L.; Demark-Wahnefried, W.; Forman, M.R.; Kurtzberg, J.; Overcash, F.; Huang, Z.; et al. Insulin-like growth factor 2/H19 methylation at birth and risk of overweight and obesity in children. J. Pediatr. 2012, 161, 31-39. [CrossRef] [PubMed]

163. Lewis, A.; Lee, J.Y.; Donaldson, A.V.; Natanek, S.A.; Vaidyanathan, S.; Man, W.D.; Hopkinson, N.S.; Sayer, A.A.; Patel, H.P.; Cooper, C.; et al. Increased expression of H19/miR-675 is associated with a low fat-free mass index in patients with COPD. J. Cachexia Sarcopenia Muscle 2016, 7, 330-344. [CrossRef] [PubMed]

164. Wang, Y.; Dang, Y.; Liu, J.; Ouyang, X. The function of homeobox genes and lncRNAs in cancer. Oncol. Lett. 2016, 12, 1635-1641. [CrossRef] [PubMed]

165. Mallo, M.; Alonso, C.R. The regulation of Hox gene expression during animal development. Development 2013, 140, 3951-3963. [CrossRef] [PubMed]

166. Bhatlekar, S.; Fields, J.Z.; Boman, B.M. HOX genes and their role in the development of human cancers. J. Mol. Med. 2014, 92, 811-823. [CrossRef] [PubMed]

167. Rinn, J.L.; Kertesz, M.; Wang, J.K.; Squazzo, S.L.; Xu, X.; Brugmann, S.A.; Goodnough, L.H.; Helms, J.A.; Farnham, P.J.; Segal, E.; et al. Functional demarcation of active and silent chromatin domains in human HOX loci by noncoding RNAs. Cell 2007, 129, 1311-1323. [CrossRef] [PubMed]

168. Hajjari, M.; Salavaty, A. HOTAIR: An oncogenic long non-coding RNA in different cancers. Cancer Biol. Med. 2015, 12, 1-9. [PubMed]

169. Tsai, M.C.; Manor, O.; Wan, Y.; Mosammaparast, N.; Wang, J.K.; Lan, F.; Shi, Y.; Segal, E.; Chang, H.Y. Long noncoding RNA as modular scaffold of histone modification complexes. Science 2010, 329, 689-693. [CrossRef] [PubMed]

170. Sun, Z.; Wu, X.Y.; Wu, C.L. The association between lncRNA HOTAIR and cancer lymph node metastasis and distant metastasis: A meta-analysis. Neoplasma 2018, 65, 178-184. [CrossRef] [PubMed]

171. Zhang, Y.; Zhou, Y.; Xu, T.; Tian, W.; Yang, C.; Wang, X.; Zhong, S.; Ran, Q.; Yang, H.; Zhu, S. Clinical value of long noncoding RNA HOTAIR as a novel biomarker in digestive cancers: A meta-analysis. Technol. Cancer Res. Treat. 2018, 17. [CrossRef] [PubMed]

172. Hruby, A.; Hu, F.B. The epidemiology of obesity: A big picture. Pharmacoeconomics 2015, 33, 673-689. [CrossRef] [PubMed]

173. Lu, X.; Bai, D.; Liu, X.; Zhou, C.; Yang, G. Sedentary lifestyle related exosomal release of HOTAIR from gluteal-femoral fat promotes intestinal cell proliferation. Sci. Rep. 2017, 7. [CrossRef] [PubMed]

174. Divoux, A.; Karastergiou, K.; Xie, H.; Guo, W.; Perera, R.J.; Fried, S.K.; Smith, S.R. Identification of a novel lncRNA in gluteal adipose tissue and evidence for its positive effect on preadipocyte differentiation. Obesity 2014, 22, 1781-1785. [CrossRef] [PubMed]

175. Kerr, J.; Anderson, C.; Lippman, S.M. Physical activity, sedentary behaviour, diet, and cancer: An update and emerging new evidence. Lancet Oncol. 2017, 18, e457-e471. [CrossRef]

176. Shen, D.; Mao, W.; Liu, T.; Lin, Q.; Lu, X.; Wang, Q.; Lin, F.; Ekelund, U.; Wijndaele, K. Sedentary behavior and incident cancer: A meta-analysis of prospective studies. PLoS ONE 2014, 9. [CrossRef] [PubMed]

(c) 2018 by the authors. Licensee MDPI, Basel, Switzerland. This article is an open access article distributed under the terms and conditions of the Creative Commons Attribution (CC BY) license (http:/ / creativecommons.org/licenses/by/4.0/). 